\title{
COMPARATIVE STUDY ON USAGE OF TEMPORALIS FASCIA Vs. PERIOSTEUM IN MYRINGOPLASTY
}

\author{
S. Surya Prakasa Raoํ, T. V. S. S. N. Leela Prasad², N. Veeraswamy33, Swathi Vadlamani ${ }^{4}$ \\ 1 Professor, Department of ENT, Andhra Medical College, Visakhapatnam. \\ ${ }^{2}$ Assistant Professor, Department of ENT, Andhra Medical College, Visakhapatnam. \\ ${ }_{3}^{3}$ Assistant Professor, Department of ENT, Andhra Medical College, Visakhapatnam. \\ 4 Post Graduate, Department of ENT, Andhra Medical College, Visakhapatnam.
}

ABSTRACT
OBJECTIVES
The aims are 1. To study the surgical results of myringoplasty using temporalis fascia as a graft material. 2. To study the surgical
results of myringoplasty using periosteum as a graft material. 3. To study the comparative outcome in myringoplasty with temporalis
fascia versus periosteum as graft materials in terms of graft uptake and hearing improvement.

\section{MATERIALS AND METHODS}

The study was conducted in Government ENT Hospital, Andhra Medical College, Visakhapatnam during the period of July 2012 to July 2014. It's a prospective study where myringoplasty was performed on 100 patients after complete examination and investigations. All patients were found to have CSOM with inactive mucosal disease with central perforation. Patients were divided into equal groups. Group 1 underwent repair of tympanic membrane by using temporalis fascia and Group 2 by using of periosteum. Post auricular approach was chosen in all the cases.

\section{CONCLUSION}

Myringoplasty is the method of choice of treatment for CSOM with inactive mucosal disease. CSOM is more common in females in this study. Out of the 100 cases 54 were females and 46 males. It is common in the age group of 15-24 years (44\%) particularly among the low socio- economic group because of lack of hygiene, ignorance and unavailability of advanced medical care. Around $90 \%$ of cases of CSOM that presented to the OPD were of safe type and required surgery. These patients were undergone reconstructive surgery using either temporalis fascia or periosteum as graft material. Good results were noted both with temporalis fascia and periosteum in terms of graft uptake and hearing restoration. Graft uptake was better with periosteum when compared to temporalis fascia. Hearing improvement better with temporalis fascia than periosteum.

\section{KEYWORDS}

Temporalis Fascia, Periosteum, Myringoplasty, CSOM.

HOW TO CITE THIS ARTICLE: Rao SSP, Prasad TVSSNL, Veeraswamy N, et al. Comparative study on usage of temporalis fascia vs. periosteum in myringoplasty. J. Evolution Med. Dent. Sci. 2016;5(35):2068-2070, DOI: 10.14260/jemds/2016/485

\section{INTRODUCTION}

Peforations in the tympanic membrane are commonly due to middle ear infections or trauma. Surgical management of perforation and hearing restoration by Myringoplasty is needed if the perforation fails to heal by conservative therapy. ${ }^{1}$ Vibratory area of the tympanic membrane is restored by Myringoplasty, thus facilitating in improving hearing and providing round window protection. It also prevents exposure of the middle ear to external infections and allergens.

Biological graft materials act as a scaffold of tissue matrix when applied to seal the perforation and this subsequently revascularises, in readiness for migration of fibroblasts and epithelium. Autologous graft materials used in Myringoplasty include vein, fat, fascia lata, temporalis fascia, periosteum, perichondrium and cartilage. Materials vary regarding their ease of harvesting, preparation time, placement ease, viability, graft uptake and hearing improvement. ${ }^{2}$

Financial or Other, Competing Interest: None.

Submission 06-02-2016, Peer Review 08-04-2016,

Acceptance 13-04-2016, Published 02-05-2016.

Corresponding Author:

Dr. S. Surya Prakasa Rao,

50-27-15/1,

Seethammadara, North East,

Visakhapatnam-530013.

E-mail:drssprao@gmail.com

DOI: $10.14260 /$ jemds $/ 2016 / 485$
However due to their anatomical proximity, translucency and suppleness, temporalis fascia and periosteum were the preferred grafting materials selected for this study.

Deafness in CSOM with inactive mucosal disease with central perforation has been challenging to the otologist for many years because of its morbidity, which needs early surgical intervention i.e Myringoplasty.3,4 Temporalis fascia is being used as a graft material for routine purposes. Even though the literature gives minimal knowledge, periosteum was selected for this study to evaluate further on it.

In adult human body, even though the periosteum is available abundantly over the bones which are superficial, the periosteum available for an ENT surgeon in the local operative and incisional area is about $120 \mathrm{~cm}$ that is temporal and mastoid area. Periosteum was selected for this study as 1 . It is available in adequate quantity 2 . Can be taken in same incision (As other grafts like vein, fat need to be taken through a separate incision and perichondrium was not chosen to avoid perichondritis) 3. Tesile strength is good. According to Mohamed Al lackany, Nadia Nassif Sarkis due to the lack of elasticity and resistance to pressure changes in the external ear canal, several authors has suggested that temporalis muscle fascia should be replaced by cartilage or strengthened by periosteium. ${ }^{4}$ 


\section{MATERIALS AND METHODS}

This prospective study has been conducted during the period of July 2012 to July 2014 on patients attending the OPD of Government ENT Hospital, Visakhapatnam, a tertiary care centre. Out of the average of 250 cases per day that attend the OPD, 60-70 were found to be suffering from CSOM.

\section{Inclusion Criteria}

Patients with CSOM with inactive mucosal disease i.e dry central perforation were selected. Study group of 100 patients, between the ages of 15-55 years underwent myringoplasty using temporalis fascia and periosteum.

\section{Exclusion Criteria}

Patients excluded from this study were those

- Below 15 years and above 55 years.

- H/o previous ear surgery/sensory neural hearing loss.

- With co-existing middle ear conditions like tympanosclerosis, ossicular discontinuity and otosclerosis.

- CSOM with granulations / polyp/ extracranial/intracranial complications.

All 100 patients were subjected to otological examination with endoscope and microscope for any evidence of polyps, granulations, oedematous mucosa. Patients with discharging ears were given antibiotics pre-operatively to achieve dry ears. Preoperative Pure tone audiometry was recorded for all cases. General examination, routine blood investigations and X-ray of mastoids were performed. After thorough pre anaesthetic check up, patients consent was taken for Myringoplasty. Advantages and complications of the surgery were explained.

Local anaesthesia was preferred as the bleeding is minimal, hearing improvement can be assessed on-table and to avoid intubation related complications. General anaesthesia was preferred in non-co-operative patients. All the patients were operated by post aural approach.

First group of 50 patients underwent Myringoplasty with Temporalis fascia by underlay technique.

Second group of 50 patients underwent Myringoplasty with periosteum by the same underlay technique. Periosteum of size $10 \mathrm{~mm} \mathrm{X} 20 \mathrm{~mm}$ was harvested from mastoid cortex below linea temporalis to tip of mastoid and kept dry.

Treatment given post operatively: Inj. Ceftriaxone 1 gm/i.v./twice daily for 7 days. Oral antihistaminics and decongestants for 2 weeks. Oral Analgesics and antiinflammatory were given. Mastoid bandage and sutures were removed on the $7^{\text {th }}$ post-operative day. Patients were advised to avoid allergic food, entry of water into ear and take advised medication regularly. They were followed up regularly for every 2 weeks for 1 month and every 3 months for 1 year.

\section{RESULTS}

\section{Sex Distribution}

In this study, 54 females and 46 males were identified.

Male to female ratio is $46: 54$. Group 1-23 males and 27 females, In Group 2 - 23 males and 27 females

\section{Age Distribution}

15-24 age group was most commonly (44\%) effected, followed by $25-34$ years $(29 \%), 35-44$ years $(14 \%)$ while $45-55$ years $(13 \%)$ was the least.

\section{Laterality of Symptoms}

Among 100 patients, 23\% were found to have bilateral disease while $77 \%$ had unilateral disease. $48 \%$ of the patients had their left ear involved while $29 \%$ had disease in the right ear.

\section{Symptomatology}

\begin{tabular}{|c|c|c|}
\hline Symptoms & No. of Cases & Percentage \\
\hline Ear discharge & 80 & $80 \%$ \\
\hline Hard of hearing & 100 & $100 \%$ \\
\hline Ear pain & 11 & $11 \%$ \\
\hline Tinnitus & 15 & $15 \%$ \\
\hline
\end{tabular}

Hard of hearing was noted to be the most common complaint with all patients, while $80 \%$ had associated ear discharge. $15 \%$ of the patients presented with tinnitus while $10 \%$ presented with ear pain

\section{Otoscopy Findings}

\begin{tabular}{|c|c|c|c|}
\hline Perforation & Group 1 & Group 2 & Total \\
\hline Anterior & 22 & 28 & 50 \\
\hline Posterior & 18 & 12 & 30 \\
\hline Subtotal & 10 & 10 & 20 \\
\hline
\end{tabular}

In the preoperative otoscopic examination, perforation in the anterior half of tympanic membrane was seen in $50 \%$ patients, while in posterior half in $30 \%$ and subtotal perforation in $20 \%$.

\section{Preoperative Hearing Assessment}

\begin{tabular}{|c|c|}
\hline $\begin{array}{c}\text { Air Bone } \\
\text { Gap (In dBs) }\end{array}$ & $\begin{array}{c}\text { No. of } \\
\text { Cases }\end{array}$ \\
\hline $0-10$ & 0 \\
\hline $10-20$ & 0 \\
\hline $20-30$ & 8 \\
\hline $30-40$ & 48 \\
\hline $40-50$ & 37 \\
\hline $50-60$ & 7 \\
\hline $60-70$ & 0 \\
\hline
\end{tabular}

Preoperative pure tone audiogram showed $48 \%$ having air bone gap around $30-40 \mathrm{db}, 37 \%$ around $40-50 \mathrm{db}, 8 \%$ have 20-30 db and 7\% have around 50-60 db.

\section{Graft Uptake}

\begin{tabular}{|c|c|c|c|c|}
\hline Graft & Total & $\begin{array}{c}\text { Take } \\
\text { Up }\end{array}$ & $\begin{array}{c}\text { Residual } \\
\text { Perf. }\end{array}$ & $\begin{array}{c}\text { Success } \\
\text { \% }\end{array}$ \\
\hline $\begin{array}{c}\text { Temporalis } \\
\text { fascia }\end{array}$ & 50 & 46 & 4 & $92 \%$ \\
\hline Periosteum & 50 & 48 & 2 & $96 \%$ \\
\hline
\end{tabular}

In this study, 4 patients had residual perforation with temporalis facia whereas 2 had residual perforation with periosteum Postoperative results after 3 months of surgery showed $92 \%$ of successful graft uptake in case of temporalis fascia where as $96 \%$ of patients with periosteum. 


\section{Hearing Improvement}

\begin{tabular}{|c|c|c|c|c|}
\hline $\begin{array}{c}\text { Hearing } \\
\text { Improvement }\end{array}$ & $\begin{array}{c}\text { post } \\
\mathbf{0 P}<\mathbf{1 5} \\
\text { DB }\end{array}$ & $\begin{array}{c}\text { post } \\
\mathbf{0 P}>\mathbf{1 5} \\
\mathbf{D B}\end{array}$ & Total & $\begin{array}{c}\text { Success } \\
\mathbf{\%}\end{array}$ \\
\hline $\begin{array}{c}\text { Temporalis } \\
\text { Fascia }\end{array}$ & 40 & 10 & 50 & $80 \%$ \\
\hline Periosteum & 38 & 12 & 50 & $76 \%$ \\
\hline
\end{tabular}

There was almost $80 \%$ improvement in hearing in patients subjected to surgery with temporalis fascia as a graft where as $76 \%$ was the hearing improvement in cases of periosteum graft.

\section{DISCUSSION}

Otitis media is a general term used to describe any inflammatory disease of the mucous membrane of the middle ear cleft. It is caused by multiple inter-related factors including infections, Eustachian tube dysfunction, allergy and barotrauma. ${ }^{5}$ Critical problem in the surgical repair of the tympanic membrane was to find a suitable grafting material. Temporalis fascia followed by perichondrium and periosteum are being used as grafting materials but the literature available in the usage of periosteum is minimal.

Temporalis fascia and periosteum are extremely thin grafts with very low metabolic requirements and have been proved to act as excellent templates for vascularization. ${ }^{6}$

In this study, we have compared the results of temporalis fascia versus periosteum grafts used for the repair of tympanic membrane using underlay technique in Myringoplasty. Both the grafts are accessible near the operative site, available in adequate amount, have excellent contour, can be thinned down and possess excellent survival capacity. ${ }^{7}$ Myringoplasty was performed on 50 cases using temporalis fascia and other 50 cases with periosteum as a graft material. It was observed that the overall uptake rate and hearing restoration with either of the grafts was almost identical. However, graft uptake was noted to be more in favour of periosteum (96\%) comparative to temporalis fascia (92\%) whereas the hearing restoration is in favour of temporalis fascia (80\%) comparative to periosteum (76\%).8,9 Periosteum holds advantage due to minimal shrinkage, excellent graft uptake

\section{CONCLUSION}

From the present study we conclude that both temporalis fascia and periosteum provide viable autograft material. Both materials are mesodermal in origin which excludes the risk of iatrogenic cholesteatoma. ${ }^{10}$ Results of hearing restoration with temporalis fascia were noted to be better than that of periosteum and graft uptake was better with periosteum than that of temporalis fascia.11,12 Hence through this study it can be said that the periosteum can also be considered as the one of the graft material for routine Myringoplasty as it has been estimated to give equal results both in closure of the perforation and also hearing improvement.

Temporalis fascia is good as a graft material in routine Myringoplasty, particularly in professionals with hearing importance. Periosteum also can be chosen as a graft material in routine myringoplasty and particularly in Revision Myringoplasty due to two reasons 1. Previous surgeon already used temporalis facia. 2. The graft uptake is better with periosteum in this observation.

\section{REFERENCES}

1. Jaisinghani VJ, Paperella MM, Schachern PA. Lect tympanic membrane correlates in chronic otitis media. Laryngoscope 1999;109(5):712-6.

2. Fisch U. Myringoplasty in Fisch $u$, may $j$ eds. Tympanoplasty, mastoidectomy and stapes surgery. sttugart; George theime verlag, 1994;9-41.

3. Storrs LA. Myringoplasty with use of fascia graft. JAMA otolarygal 1961;74(1):45-9.

4. Mohamed Al lackany, Nadia Nassif Sarkis. Functional results after myringoplasty and type 1 tympanoplasty with the use of different graft materials. Journal of the Medical Research Institute 2005;26(4):369-74.

5. Hentzer E. Ultra structure of human tympanic memebrane. Acta oto laryngological 1969;68(1-6):376-90.

6. Albert PW. Epithelial migration over tympanic membrane and external auditory canal. Journal of laryngology and otology 1964;78:808-30.

7. Merchant SN, Mckenna MJ, Rosowski JJ. Current status and futre challenges of tympanoplasty. European archives of otorhinolaryngology 1998;255(5):221-8.

8. Black JH, Wormold PJ. Myringoloplasty effects on hearing and contributing factors. South African medical journal 1995;85(1):41-3.

9. Meyer AG, Albers FW. Validation of hearing results in tympanoplasty. In: Huettenbrink ed. Middle ear mechanics in researches and otosurgery, 1997;147-50.

10. Palva T, Ramsay H. Myringoplasty and tympanoplastyresults related to training and experience. Clinical otolaryngology and allied sciences 1998;23:177-80.

11. Salmaz MA, Yucel EA, Ozdemir M, et al. Comparison of hearing levels and tympanic membrane healing obtained bycartilage palisade and temporal fascia in tympanoplasty technique: preliminary results. Kulak Burun Bogaz Ihtis Derg 2002;9(4):271-4.

12. Gierek T, Slaska KA, Majzel K, et al. Results of myringoplasty and type 1 tympanoplasty with the use of fascia, cartilage and perichondrium grafts. Otolaryngol Pol 2004;58(3):529-33. 